\title{
A study of the abilities in oral language comprehension of the Boston Diagnostic Aphasia Examination - Portuguese version: a reference guide for the Brazilian population
}

L.L. Mansur ${ }^{1}$, M. Radanovic ${ }^{2}$, L. Taquemori ${ }^{3}$, L. Greco ${ }^{3}$ and G.C. Araújo ${ }^{3}$

\author{
${ }^{1}$ Departamento de Fisioterapia, Fonoaudiologia e Terapia Ocupacional, \\ ${ }^{2}$ Departamento de Neurologia, and ${ }^{3}$ Departamento de Fonoaudiologia, CAP/FUNDAP, \\ Hospital das Clínicas, Faculdade de Medicina, Universidade de São Paulo, São Paulo, \\ SP, Brasil
}

\section{Correspondence}

M. Radanovic

Rua Cristiano Viana, 163, Apto. 92

05411-000 São Paulo, SP

Brasil

Fax: + 55-11-3088-9708

E-mail: radano@tecway.com.br

Publication supported by FAPESP. $\ldots \ldots \ldots \ldots \ldots \ldots$

Received October 15, 2003 Accepted December 9, 2004

\begin{abstract}
We analyzed the performance of 162 normal subjects, subdivided into groups according to age and schooling, in the oral comprehension tasks of the Boston Diagnostic Aphasia Examination translated and adapted to Brazilian Portuguese to obtain a profile of performance for the Brazilian population, as well as cut-off scores for each task, and to determine the best combination of tasks that distinguish normal from aphasic subjects, as a guide for clinicians. The normal subjects were compared to 69 aphasics. Age alone influenced the performance in the designation of actions (subjects above 70 years showing the worst performance); schooling alone influenced the comprehension of forms, colors and numbers (subjects with less than four years of education showing a poorer performance). Both age and schooling influenced the performance in Body Part Identification (BPI) and Complex Ideational Material (CIM) with mean values of $70.5 \pm 3.3$ (Word Discrimination, WD), $18.9 \pm 1.4$ (BPI), $14.7 \pm 0.9$ (Commands), and $10.3 \pm 1.7$ (CIM) for the whole sample; the cut-off scores obtained were 65 (WD), 17.5 (BPI), 14 (Commands), and 9.5 (CIM) for the whole sample. Logistic regression showed that the combination of BPI + Commands + CIM was the most efficient in differentiating normal subjects from aphasics, with $72.5 \%$ sensitivity and $97.6 \%$ specificity. However, for low-education subjects, BPI and Commands were sufficient for this differentiation ( $75.7 \%$ sensitivity and $84.7 \%$ specificity). The main contribution of this study was to provide reference values that are far more representative of our population to be used by health professionals in Brazil, taking into account cultural differences.
\end{abstract}

Key words

- Oral comprehension

- Age

- Schooling

- Boston Diagnostic Aphasia

Examination

- Brazilian Portuguese 


\section{Introduction}

The evaluation of language comprehension is not a simple task since it involves the consideration of language processing abilities directly or indirectly interacting with other cognitive capacities (1). Comprehension alterations refer to impairment in the domain of expressed concepts in the lexicon of several semantic categories and specific parts of speech (verbs, nouns, pronouns, adjectives, adverbs, prepositions, conjunctions, articles) as well as to the capacity to interpret sentences and texts. With regard to texts, some authors use the terms "comprehension" and "memorization" synonymously (2).

Cognitive effects related to socio-demographic variables, such as educational level, have been studied in countries with large contingents of socioculturally disadvantaged populations since these effects influence performance in cognitive and language tests (3-6).

These populations involve a broad spectrum which includes illiterate people with a high degree of sociocultural deprivation and other subgroups with varying degrees of social disadvantage. Although illiteracy, understood as a complete reading inability, has been considerably attenuated in Brazil, there is still a large contingent of individuals considered to be functionally illiterate, defined as those with less than 4 years of schooling (7). In the southeastern region, for instance, in a sample of 1000 subjects living in São Paulo, ranging in age from 15 to 54 years, $20.4 \%$ had attended school for less than four years. Among other impairments, a consistent correlation between low reading level and low auditory comprehension has been observed (8). These difficulties are aggravated in situations that require metacognitive and metalinguistic operations such as those found in language tests that exclude contextual information, which comprises an important source of inferences used for comprehension (9).
There is no consensus about the concept of functional illiteracy, with the main divergences being related to the degree of efficiency in reading use. The number of years of formal education has been considered to be an important indicator to estimate competence; however, this variable can assume different meanings in several cultures and in different countries. For some investigators, although these individuals can "develop daily activities, they lack the basic abilities to live well in society", which include social, language and communication skills. Moreover, it is known that the difficulties in comprehension are more frequent among older people, increasing proportionally with age and causing an overlapping of problems (10-12).

Aphasia, as well as language disturbances in dementia and head trauma, can also provoke difficulties in verbal comprehension. Moreover, an issue still not entirely resolved in Neurolinguistics practice is the possible influence of age and education on the incidence and nature of the type of cognitive alterations seen in cerebral lesions. Concerning educational level, most of these studies refer to the effect of the social conditions on aphasia frequency, type and recovery (1315). A number of investigators have been more interested in the manifestation of dementias and their relationship with educational level $(16,17)$. The influence of demographic variables such as age and education on the performance of brain-damaged patients is controversial. There is some evidence that this influence is significant in normal subjects but not in such patients, when considering the global scores in neuropsychological tests (18). Other studies have confirmed this interference, particularly in language tests that involve the comprehension of spatial relations (19) or in auditoryverbal tests (20).

Ardila (21) argues that neuropsychological tests, including those of language, had certain normality standards determined by the performance of North American middle- 
class individuals, and should not be applied to other cultures with distinct educational cognitive levels. The author suggests that the normality standards must be established for different age groups, cultures and educational levels and others also recommend the modification or withdrawal of language tasks that are not important to a particular group $(22,23)$.

In Brazil, Bertolucci et al. (24), evaluating global cognitive aspects using the Mini-Mental Status Examination (MMSE) in 530 subjects, and classifying the subjects according to age and schooling, verified that age alone did not interfere with the scores obtained, while educational level led to statistically significant differences among four levels of formal education.

In the evaluation of Brazilian subjects who were cognitively healthy, literate and of low educational level, with tests of linguistic competence and other functions, it was observed (3) that those of low education presented a greater number of errors than those with higher education, in the oral comprehension tasks, in words and in simple and complex sentences.

The Boston Diagnostic Aphasia Examination (BDAE) (25) is one of the tests most commonly employed to evaluate aphasics. It is a scanning test used to detect and evaluate aphasia involving metalinguistic tasks. Studies with the BDAE have already demonstrated that individuals of low educational level present differences in performance relative to those that had greater access to formal education in the majority of the tasks. Pineda et al. (4) analyzed the effects of age, gender, occupation, educational, and cultural level on the scores of language tasks in subjects without neurological disturbances. They observed that 1 to $3 \%$ of the sample presented scores within the pathological range for aphasia diagnosis. In multivariate analysis, they also observed that educational level significantly influenced the majority of subtests. The Visual Confrontation Naming,
Oral Reading, Serial Writing, and Dictation tasks were age-sensitive, while occupation had minimal effects on performance. Thus, the authors concluded that the BDAE is sensitive to demographic variables, in particular to educational level.

In the BDAE, oral language reception is verified in a global way throughout the whole examination and, more particularly, in a set of tasks involving both word comprehension and the understanding of sentences and texts. These subtests are composed of stimuli that are graded in difficulty according to semantic and syntactic criteria. Six different semantic categories are presented to evaluate samples of the mental lexicon, as well as sentences with sequential actions and texts that demand the processing of an increasing number of explicit and implicit information items.

It is our opinion that Brazilian reference profiles are necessary to identify and distinguish cultural peculiarities from language disturbances and other "sociocultural impairments", given the lack of studies concerning these aspects in our country. The present study, was designed to evaluate the performance of normal subjects, focusing on oral comprehension skills and taking into account the influence of age and schooling. We also aimed to determine cut-off scores for the Brazilian population in these tasks by comparison with a sample of aphasic subjects, and to identify which combination of tasks could better distinguish normal subjects from aphasics, as an algorithm to guide clinical practice. We expected to find some influence of age and schooling on the performance of subjects, as pointed out in the literature.

\section{Subjects and Methods}

We studied 162 individuals of both genders (54 males, 33.4\%, and 108 females, $66.6 \%$ ) classified into four groups according to age (A: 15 to 30, B: 31 to 50, C: 51 to 70 , 
and D: above 70 years), and into three groups according to educational level (1: 1 to 4, 2: 5 to 8, and 3: 9 or more years).

Our sample of normal subjects was recruited among patients' companions in the Neurology Outpatient Service of the University Hospital, University of São Paulo School of Medicine and in literacy courses for adults in our community. The criteria for inclusion in the sample were: a) age above 15 years; $b$ ) Portuguese native speaker; c) absence of visual and hearing deficits (not adequately corrected by proper devices); d) no neurological or psychiatric background, including alcoholism and illegal drug abuse (data obtained from interview) e), normal MMSE scores for the Brazilian population (24), and f) normal scores in the functional daily activities scale (26). All participants in this study signed informed consent forms and the study was approved by the Ethics Committee for Analysis of Research Projects, University Hospital, Medical School, University of São Paulo.

The subjects were submitted to the Auditory Comprehension battery from the BDAE translated and adapted to Brazilian Portuguese (27). This battery is composed of four subtests, as follows (for further description of stimuli and scoring, see Appendix):

Word Discrimination. A multiple-choice auditory recognition test sampling six semantic categories (objects, geometric forms, letters, actions, numbers, and colors). The patient must point to the figure that has been previously named by the examiner on a test card containing three semantic categories of visual stimuli.

Body Part Identification. It presents a sample of 18 body-part names of increasing difficulty, which the patient must point at on his own body after the examiner's request.

Commands. The patient must carry out oral commands supplied by the examiner, in increasing degrees of complexity (from one to five units of information).
Complex Ideational Material. The patient has to agree or disagree with a series of proposals presented orally by the examiner; the material increases progressively in length and in the demand for inferences and use of previous knowledge.

Data regarding the performance of normal subjects were analyzed statistically using the SPSS (Statistical Package for Social Sciences ${ }^{\circledR}$ ) software version 10.0 and MedCalc ${ }^{\circledR}$ software version 7.2.0.2. A multifactorial analysis of variance (MANOVA) including multiple comparisons followed by the post hoc Dunnett test was used to compare the effects of age and education on the BDAE oral comprehension subtests.

The performance of the normal group was then compared to that of a group of 69 aphasics in order to obtain cut-off scores (with the respective sensitivities, specificities and area under the curve values) differentiating controls from aphasics in the total sample, and within the different education subgroups, through receiver operating characteristic curve analysis. The aphasic patients were selected from a sample of outpatients attended at our Neurolinguistics Unit, all having complaints involving language impairment and presenting objective alterations both in functional evaluation and in the BDAE, in addition to having neuroimaging exams showing damage in the left hemisphere, affecting brain areas related to language (this sample has been described in a previous study published by the authors, 28).

We also performed a forward stepwise logistic regression analysis to determine which association of tasks better discriminated normal subjects from aphasics in the distinct educational levels. A value of $\mathrm{P}<0.05$ was considered statistically significant for all analyses.

\section{Results}

The age of normal subjects ranged from 
15 to 84 years $($ mean $\pm S D=47.5 \pm 16.7$ years), and educational level, defined as time devoted to formal study, ranged from 1 to 24 years $(8 \pm 4.7$ years). The age of the aphasic subjects ranged from 16 to 83 years $(51.4 \pm$ 16.3 years) and educational level ranged from 0 to 16 years $(7.2 \pm 4.8$ years). There were no statistically significant differences in age or schooling between these two groups ( $\mathrm{P}=0.1$ and 0.24 , respectively).

The mean number of years of education was $9.62 \pm 5$ in group A (15 to 30 years), $8.47 \pm 4.97$ in group B (31 to 50 years), 7.51 \pm 4.33 in group C (51 to 70 years), and 4.6 \pm 2.66 in group D (above 70 years). There was a statistically significant difference between groups $\mathrm{A}$ and $\mathrm{D}(\mathrm{P}<0.01)$, and $\mathrm{B}$ and $\mathrm{D}(\mathrm{P}<0.05)$, with group $\mathrm{D}$ being the least educated. The demographic data are presented in Table 1.

Age as a single variable influenced the performance of subjects in the Word Discrimination for the semantic category actions, where group D (above 70 years) presented the worse performance $(\mathrm{P}=0.019)$. The schooling variable, alone, influenced performance in Word Discrimination: there were statistical differences among groups in the global performance and in geometric forms (group 1 performed worse than groups 2 and 3), colors and numbers (group 1 performed worse than group 3 ).

Both age and schooling influenced the performance in Body Part Identification and
Complex Ideational Material, but it was not possible to isolate the effect of each variable separately in this sample, especially in group D. In Body Part Identification, group D (above 70 years) performed worse than groups $\mathrm{A}, \mathrm{B}$ and $\mathrm{C}$, and there were significant differences between the three educational level groups ( 1 vs 2, 1 vs 3, and 2 vs 3). In Complex Ideational Material, group 3 presented better results when compared to groups 1 and 2, and group D performed worse than groups A, B and C. The overall scores per age and educational level can be seen in Tables 2, 3 and 4. The MANOVA and multiple comparison results are displayed in Tables 5 and 6 .

The cut-off scores that differentiated aphasics from controls in each sub-item of the oral comprehension test are presented in Table 7, with the respective sensitivities and specificities, according to educational level. The results of logistic regression analysis are presented in Table 8. These show that Word Discrimination was the task with lowest differentiation power between aphasics and controls; on the other hand, Body Part Identification was a discriminative factor for all groups. Commands contributed to discrimination in the lower (1 and 2), but not in the higher educational level group (3). In contrast, Complex Ideational Material did not play any role in differentiation in the less educated group (1), as it did in the more educated groups (2 and 3 ).

Table 1. Demographic data of the study population.

\begin{tabular}{|c|c|c|c|c|c|c|}
\hline & \multicolumn{4}{|c|}{ Age (years) } & \multirow[t]{2}{*}{ Total (\%) } & \multirow[t]{2}{*}{ Mean $\pm S D$} \\
\hline & $\begin{array}{c}\text { Group A } \\
(15-30)\end{array}$ & $\begin{array}{l}\text { Group B } \\
(31-50)\end{array}$ & $\begin{array}{c}\text { Group C } \\
(51-70)\end{array}$ & $\begin{array}{c}\text { Group D } \\
(>70)\end{array}$ & & \\
\hline \multicolumn{7}{|l|}{ Education } \\
\hline Group 1 (1-4 years) & 9 & 17 & 23 & 9 & $58(35.8)$ & $3.3 \pm 0.99$ \\
\hline Group 2 (5-8 years) & 0 & 16 & 22 & 4 & 42 (25.9) & $6.9 \pm 1.3$ \\
\hline Group 3 ( $\geq 9$ years) & 24 & 22 & 15 & 1 & 62 (38.3) & $13.2 \pm 2.9$ \\
\hline Total subjects (\%) & $33(20.4)$ & 55 (33.9) & $60(37)$ & $14(8.7)$ & $162(100)$ & \\
\hline Mean age $\pm S D$ & $22.9 \pm 4.37$ & $41.9 \pm 5.9$ & $58.5 \pm 5.7$ & $74.8 \pm 4.5$ & & \\
\hline
\end{tabular}


Table 2. Scores of subjects in oral comprehension tasks according to age.

\begin{tabular}{lcccc}
\hline Task & Group & Mean \pm SD & $95 \% \mathrm{Cl}$ & Range \\
\hline Word Discrimination & A & $70.6 \pm 3.2$ & $69.5-71.8$ & $56-72$ \\
& B & $70.6 \pm 2.8$ & $69.8-71.5$ & $61-72$ \\
& C & $70.4 \pm 3.7$ & $69.5-71.4$ & $48-72$ \\
& D & $69.5 \pm 3.3$ & $67.8-71.2$ & $62-72$ \\
& Total & $70.5 \pm 3.3$ & $69.9-70.9$ & $48-72$ \\
Body Part Identification & & & & \\
& A & $18.5 \pm 1.9$ & $18.1-18.9$ & $13-20$ \\
& B & $18.7 \pm 1.6$ & $18.0-18.8$ & $16-20$ \\
& C & $19.0 \pm 1$ & $18.7-19.4$ & $16-20$ \\
Commands & D & $19.6 \pm 0.5$ & $19.3-19.9$ & $17-20$ \\
& Total & $18.9 \pm 1.4$ & $18.7-19.1$ & $13-20$ \\
& A & $14.8 \pm 0.6$ & $14.6-15.0$ & $12-15$ \\
& B & $14.8 \pm 0.9$ & $14.5-15.0$ & $10-15$ \\
& C & $14.8 \pm 0.9$ & $14.5-14.9$ & $10-15$ \\
& D & $14.4 \pm 1.3$ & $13.7-15.2$ & $11-15$ \\
& Total & $14.7 \pm 0.9$ & $14.6-14.8$ & $10-15$ \\
& & & & \\
& A & $10.2 \pm 2$ & $9.5-11.0$ & $5-12$ \\
& B & $10.4 \pm 1.9$ & $9.9-11.0$ & $5-12$ \\
& C & $10.3 \pm 1.3$ & $10.0-10.7$ & $7-12$ \\
& D & $9.7 \pm 1.7$ & $8.8-10.6$ & $6-12$ \\
& Total & $10.3 \pm 1.7$ & $10.0-10.5$ & $5-12$ \\
\hline
\end{tabular}

$\mathrm{Cl}=$ confidence interval. See Table 1 for explanation of groups.

Table 3. Scores of subjects in oral comprehension tasks according to educational level.

\begin{tabular}{lcccr}
\hline Task & Group & Mean \pm SD & $95 \% \mathrm{Cl}$ & Range \\
\hline Word Discrimination & 1 & $68.9 \pm 4.6$ & $67.7-70.1$ & $48-72$ \\
& 2 & $71.0 \pm 1.9$ & $70.4-71.7$ & $64-72$ \\
& 3 & $71.5 \pm 1.6$ & $71.0-71.9$ & $62-72$ \\
& Total & $70.5 \pm 3.3$ & $69.9-70.9$ & $48-72$ \\
Body Part Identification & & & & \\
& 1 & $18.0 \pm 1.7$ & $17.6-18.5$ & $13-20$ \\
& 2 & $19.0 \pm 1.2$ & $18.7-19.4$ & $16-20$ \\
& 3 & $19.7 \pm 0.6$ & $19.6-19.9$ & $16-20$ \\
Commands & $18.9 \pm 1.4$ & $18.7-19.1$ & $13-20$ \\
& 1 & $14.5 \pm 1.2$ & $14.2-14.8$ & $10-15$ \\
& 2 & $14.8 \pm 0.7$ & $14.6-15.0$ & $11-15$ \\
& 3 & $14.9 \pm 0.6$ & $14.7-15.0$ & $10-15$ \\
& & $14.7 \pm 0.9$ & $14.6-14.8$ & $10-15$ \\
Total & & & \\
& 1 & $9.5 \pm 1.9$ & $8.9-9.9$ & $5-12$ \\
& 2 & $11.3 \pm 0.0 \pm 1.5$ & $9.6-10.5$ & $6-12$ \\
& 3 & $10.3 \pm 1.7$ & $11.0-11.5$ & $7-12$ \\
& Total & & & $5-12$ \\
\hline
\end{tabular}

$\mathrm{Cl}=$ confidence interval. See Table 1 for explanation of groups . 
Table 4. Scores of subjects in the Word Discrimination task (semantic categories) according to educational level.

\begin{tabular}{|c|c|c|c|c|}
\hline Task & Group & Mean \pm SD & $95 \% \mathrm{Cl}$ & Range \\
\hline \multirow{4}{*}{ Objects } & 1 & $11.6 \pm 0.9$ & $11.4-11.9$ & 8-12 \\
\hline & 2 & $11.9 \pm 0.3$ & $11.8-12.0$ & $10-12$ \\
\hline & 3 & $11.7 \pm 1.3$ & $11.4-12.0$ & 2-12 \\
\hline & Total & $11.7 \pm 1.0$ & $11.6-11.9$ & $2-12$ \\
\hline \multirow[t]{4}{*}{ Letters } & 1 & $11.7 \pm 0.9$ & $11.5-12.0$ & $6-12$ \\
\hline & 2 & $12.0 \pm 0$ & $12.0-12.0$ & $12-12$ \\
\hline & 3 & $12.0 \pm 0$ & $12.0-12.0$ & $12-12$ \\
\hline & Total & $11.9 \pm 0.5$ & $11.8-12.0$ & $6-12$ \\
\hline \multirow[t]{4}{*}{ Geometric forms } & 1 & $10.7 \pm 1.7$ & $10.3-11.2$ & $4-12$ \\
\hline & 2 & $11.5 \pm 1$ & $11.2-11.9$ & 8-12 \\
\hline & 3 & $11.9 \pm 0.4$ & $11.8-12.0$ & 10-12 \\
\hline & Total & $11.4 \pm 1.3$ & $11.2-11.6$ & $4-12$ \\
\hline \multirow[t]{4}{*}{ Actions } & 1 & $11.7 \pm 0.9$ & $11.4-11.9$ & 8-12 \\
\hline & 2 & $11.9 \pm 0.6$ & $11.7-12.1$ & 8-12 \\
\hline & 3 & $11.9 \pm 0.4$ & $11.8-12.0$ & $10-12$ \\
\hline & Total & $11.8 \pm 0.7$ & $11.7-11.9$ & $8-12$ \\
\hline \multirow[t]{4}{*}{ Colors } & 1 & $11.5 \pm 1.1$ & $11.2-11.7$ & $7-12$ \\
\hline & 2 & $11.7 \pm 0.9$ & $11.4-12.0$ & 8-12 \\
\hline & 3 & $11.9 \pm 0.4$ & $11.8-12.0$ & $9-12$ \\
\hline & Total & $11.7 \pm 0.8$ & $11.6-11.8$ & $7-12$ \\
\hline \multirow[t]{4}{*}{ Numbers } & 1 & $11.6 \pm 1.2$ & $11.3-11.9$ & $6-12$ \\
\hline & 2 & $11.9 \pm 0.3$ & $11.8-12.0$ & $10-12$ \\
\hline & 3 & $11.9 \pm 0.1$ & $11.9-12.0$ & $11-12$ \\
\hline & Total & $11.8 \pm 0.7$ & $11.7-11.9$ & 6-12 \\
\hline
\end{tabular}

$\mathrm{Cl}=$ confidence interval. See Table 1 for explanation of groups.

Table 5. MANOVA results for each task considering age and schooling factors.

\begin{tabular}{lccc}
\hline Task & Age factor & Schooling factor & Age and schooling \\
\hline Word Discrimination & & & - \\
$\quad$ Objects & - & - & - \\
Letters & - & - & - \\
Geometric forms & - & 0.001 & 0.065 \\
Actions & 0.019 & 0.012 & - \\
Colors & - & 0.01 & - \\
Numbers & - & 0.006 & 0.001 \\
Total & - & 0.0001 & - \\
Body Part Identification & 0.0001 & - & 0.016 \\
Commands & - & 0.0001 & - \\
Complex Ideational Material & 0.025 & & \\
\hline
\end{tabular}

The numbers indicate the level of significance when $\mathrm{P} \leq 0.05$ for differences among groups (considering the age and schooling factors separately and their interaction) in the performance of the tasks. When no value is reported, $\mathrm{P}>0.05$. 
Table 6. Results of multiple comparisons showing inter-group differences and the respective level of significance for each task (MANOVA with Dunnett post-test).

\begin{tabular}{|c|c|c|c|}
\hline Task & Age factor & Schooling factor & Age and schooling \\
\hline \multicolumn{4}{|l|}{ Word Discrimination } \\
\hline Objects & - & - & - \\
\hline Letters & - & - & - \\
\hline Geometric forms & - & 1 vs $2(0.005)$ and 1 vs $3(<0.001)$ & - \\
\hline Actions & D vs $A, B$ and $C$ (0.019) & - & - \\
\hline Colors & - & 1 vs 3 (0.009) & - \\
\hline Numbers & - & 1 vs $3(0.04)$ & - \\
\hline Total & - & 1 vs $2(0.007)$ and 1 vs 3 (0.001) & - \\
\hline \multirow{6}{*}{ Body Part Identification } & - & - & A vs D (0.023) \\
\hline & - & - & $\mathrm{B}$ vs D (0.004) \\
\hline & - & - & C vs D (0.04) \\
\hline & - & - & 1 vs $2(0.002)$ \\
\hline & - & - & 1 vs $3(<0.001)$ \\
\hline & - & - & 2 vs $3(0.004)$ \\
\hline Commands & - & - & - \\
\hline \multirow[t]{2}{*}{ Complex Ideational Materi } & aterial & - & 1 vs $3(<0.001)$ \\
\hline & - & - & 2 vs $3(<0.001)$ \\
\hline
\end{tabular}

See Table 1 for explanation of groups.

Table 7. Cut-off scores, sensitivity and specificity in the Auditory Comprehension tasks according to schooling.

\begin{tabular}{lcccc}
\hline Task & Cut-off score & Sensitivity (\%) & Specificity (\%) & AUC (95\% CI) \\
\hline Group 1 & & & & \\
WD & 65.0 & 65.7 & 86.0 & $0.76(0.68-0.83)$ \\
BPI & 15.5 & 65.2 & 93.0 & $0.82(0.74-0.88)$ \\
Commands & 14.0 & 74.3 & 80.7 & $0.81(0.73-0.88)$ \\
CIM & 7.5 & 68.6 & 84.2 & $0.82(0.74-0.88)$ \\
Group 2 & & & & \\
WD & 65.0 & 64.3 & 97.6 & $0.84(0.76-0.9)$ \\
BPI & 17.5 & 81.2 & 87.8 & $0.88(0.8-0.94)$ \\
Commands & 14.0 & 74.3 & 95.2 & $0.85(0.77-0.91)$ \\
CIM & 7.5 & 67.1 & 92.7 & $0.87(0.79-0.92)$ \\
Group 3 & & & & \\
WD & 70.0 & 76.8 & 89.7 & $0.87(0.8-0.92)$ \\
BPI & 18.0 & 86.8 & 96.6 & $0.94(0.88-0.97)$ \\
Commands & 14.0 & 74.3 & 94.7 & $0.85(0.78-0.91)$ \\
CIM & 10.5 & 94.2 & 87.9 & $0.95(0.9-0.98)$ \\
Total & & & & \\
WD & 65.0 & 65.7 & 94.0 & $0.83(0.76-0.89)$ \\
BPI & 17.5 & 82.6 & 83.7 & $0.88(0.83-0.94)$ \\
Commands & 14.0 & 74.3 & 90.4 & $0.84(0.77-0.9)$ \\
CIM & 9.5 & 85.7 & 74.5 & $0.88(0.83-0.93)$ \\
\hline
\end{tabular}

Data were submitted to receiver operator characteristic analysis. WD $=$ Word Discrimination; BPI $=$ Body Part Identification; $\mathrm{CIM}=$ Complex Ideational Material; $\mathrm{Cl}=$ confidence interval; $\mathrm{AUC}=$ area under the curve. See Table 1 for explanation of groups. 


\begin{tabular}{|c|c|c|c|c|}
\hline \multirow[t]{2}{*}{ Group } & \multicolumn{2}{|c|}{ Observed } & \multicolumn{2}{|c|}{ Predicted } \\
\hline & Variable & Normal & Aphasics & \% Correct \\
\hline \multicolumn{5}{|l|}{ Group 1} \\
\hline \multirow[t]{3}{*}{$\mathrm{BPI}+$ Commands } & Normal & 50 & 9 & 84.7 \\
\hline & Aphasics & 17 & 53 & 75.7 \\
\hline & Overall \% & & & 79.8 \\
\hline \multicolumn{5}{|l|}{ Group 2} \\
\hline \multirow[t]{3}{*}{$\mathrm{BPI}+$ Commands + CIM } & Normal & 37 & 5 & 88.1 \\
\hline & Aphasics & 11 & 59 & 84.3 \\
\hline & Overall \% & & & 85.7 \\
\hline \multicolumn{5}{|l|}{ Group 3} \\
\hline \multirow[t]{3}{*}{$\mathrm{BPI}+\mathrm{CIM}$} & Normal & 57 & 3 & 95.0 \\
\hline & Aphasics & 6 & 64 & 91.4 \\
\hline & Overall \% & & & 93.1 \\
\hline \multicolumn{5}{|l|}{ Total } \\
\hline \multirow[t]{3}{*}{$\mathrm{BPI}+$ Commands + CIM } & Normal & 161 & 4 & 97.6 \\
\hline & Aphasics & 19 & 50 & 72.5 \\
\hline & Overall \% & & & 90.2 \\
\hline
\end{tabular}

\section{Discussion}

The neurolinguistics literature describes impairments in the ability to comprehend oral language in aphasia, dementia, right hemisphere damage, and head trauma. We can identify difficulties in the processing of simple aspects (such as auditory discrimination, the access to, or even the disposal of, the meaning of words referring to objects, people, ideas, and experiences), or in establishing more complex abstract relationships among components of a sentence and extracting the meaning of a text. Although the tests used to evaluate comprehension seek pathological alterations, they are not devoid of interference from factors such as age and schooling.

The statistical difference in educational level found among groups A, B and D represents a trend in developing countries - i.e., the increasing access to fundamental education due to government policies on illiteracy eradication and prevention of school truancy - but is not always accompanied by a real qualitative improvement in performance in language functional use or in everyday life, or in test situations. However, since the general results did not show important fluctuations in the performance according to age (except for the designation of actions), this difference had little effect on data interpretation.

The age factor alone influenced the differences in the results among groups in the comprehension of actions, a finding that has not been referred to in previous studies using the $\operatorname{BDAE}(4,5,29)$. There is no reason to believe that such difficulties might be related to the specific comprehension of verbs. In this task, the subject must interpret actions drawn in black and white. These figures representing actions have a complex presentation, demanding a larger number of visual inferences than the isolated objects used in the other designation tasks, where the drawings show, in a more detailed manner, the essential and prototypical outline of the target object. A transitive action, for example, demands the presentation of the agent and of the object on which it occurs. It is from this relationship that we extract the meaning of a verb. Recently, studies emphasizing the incapacity to peform complex visual analysis 
have been considered promising towards furthering the understanding of cognitive processing in the elderly (30). Although subjects who reported visual difficulties were excluded from the study, it is possible that the demand for perceptual abilities for details in designating actions is beyond the capabilities of these elderly subjects. The treatment of information involving verbs warrants further investigation in the elderly population. We must also consider a possible influence of the previously described lower educational level found in this group (Table 1).

Schooling, as an isolated variable, influenced the groups in tasks of recognition of geometric forms, colors and numbers, which indicates restrictions in the mental dictionary domain (semantic system, influenced by the culture level, habits and exposure to language). Geometric forms (cone, ellipse, spiral) and numbers less frequently used in everyday life and involving complex syntax, such as thousand, were the source of a greater number of mistakes.

The Commands subtest is characterized by the presentation of stimuli with increasing levels of difficulty in terms of phrase length, and both the syntactic and textual structures. For this task, the performance according to age and schooling was similar for all groups.

Both age and schooling influenced the performance in Body Part Identification and Complex Ideational Material. At this point, it is important to remember that in our sample the elderly were less educated (group D was less educated than groups A and B), and it was not possible to evaluate the effect of each variable (either age or schooling) as a single factor on the performance of this group. Moreover, in the results obtained for group 1 we cannot rule out a possible crossinfluence of older age.

The results for Body Part Identification are intriguing, although yet unexplained, but similar findings have been reported by Pineda et al. (4). When asked to identify a particular item, the less educated individual does not know the necessary lexicon for the task, particularly in details, such as the name of fingers.

In Complex Ideational Material, there is a sentence judgment task in the first part while the second part demands comprehension, retention and retrieval of the information presented in the texts. The differences found for text interpretation support the position advocated by Ryan and Manly $(31,32)$, who emphasize the effect of the lack of formal education on the difficulty in comprehending complex material among the elderly, superposed to age per se. The fact that people older than 65 years of age had fewer opportunities to attend school is well recognized in several countries, especially in less developed ones, according to UNESCO reports $(32,33)$. However, we must consider that this position differs from that held by the majority of investigators, who report comprehension deficits in the elderly (10-12). Recently, the controversies regarding comprehension deficits in the elderly have been studied in situations in which the manner of text presentation was controlled, since results suffer the effects of presentation rhythm and intonation, among other aspects $(2,34)$. In our study, the texts were presented in a silent room, with the examiner and the subject face-to-face and after the solicitation of attention. Another point worthy of note is that the elderly who normally show difficulties in comprehension are those aged over 75 years (elderly-elderly), whereas those in our study were aged under 75 years, a group presenting no significant differences related to age, which, in our view, favors the influence of schooling.

In general, our findings regarding the Word Discrimination, Commands and Complex Ideational Material tasks agree with those reported by Parente and Lecours (3), Lecours et al. (35) and Pineda et al. $(4,5)$ in that we observed the same significant differences in the performance of subjects of distinct educational levels. 
We expected the less educated individuals to have worse performance when compared to those with higher educational level in Complex Ideational Material, which was, in fact, the case. Subjects with more than eight years of schooling (group 3) presented advantages in this task. Below this level, formal education did not significantly influence the ability of the subjects in text interpretation: group 2, although more educated, did not differ from group 1.

Although they are presented orally, the four texts of this subtest have a constitution that follows the patterns of written language, particularly with respect to the absence of redundant information. In the organization of sentences, although coordinate syntactic constructions predominate (typical of the oral language), other elements that indicate "meaning blocks" in the oral modality are absent (pauses, ellipses), while the rules of the written language predominate in the presentation. The themes and the lexicon used do not present difficulties for the populations that live in São Paulo and that are exposed to the media. One text differs from another regarding the degree of inference required for apprehension and organization of data, volume of essential information and of distractors. In the first text, the information is explicit and the items to be comprehended are few, whereas in the second, the number of distractors to be eliminated for comprehension of essential elements is higher; the third text, however, has the characteristics of a joke with a double meaning and figurative language; the fourth involves a greater volume of information, as well as the apprehension of some implicit information. Difficulties related to the linguistic processes (such as word recognition and reduction of the basic syntactic knowledge required in order to determine a typical sentence) and others implied in global cognitive processes (such as the reduction of short-term memory and of the flexibility to adopt strategies), usually associated with illiteracy $(6,36)$, can appear in several degrees in the literate, according to the degree of exposure to formal education.

When analyzing educational level and its effect on the performance in tests, we must bear in mind that the BDAE includes tasks that refer to the school context (cards, pencil, paper, listening to the teacher, following instructions, and the emphasis on metalinguistic tasks), which are sensitive to the subject's previous experience in these conditions. The oral comprehension tasks require auditory presentation, dissociating visual support, in a bid to minimize the contextual and cultural effects related to visual perception, which does not prevent other difficulties in abstract processing from being evident.

The separate analysis of semantic categories in Word Discrimination revealed an original contribution, as the influence of semantic categories on the subjects' performance had not hitherto been described in detail in other Hispanic studies $(4,5)$. These findings allow the evaluation of schooling influence on the mental dictionary.

Another important issue is ascertaining whether the oral comprehension tests are useful to correctly and reliably differentiate aphasic patients from normal low-educated subjects. We noticed that the score averages obtained by less educated subjects differed statistically from those described for a population of Brazilian aphasics, indicating that the influence of low education on the subjects' performance does not place them in the pathological range, providing their demographic characteristics are respected. Subjects with less than eight years of formal education could be considered as having comprehension impairment had they been classified according to North American scoring. This occurs because the North American scores were obtained from a population with a minimum of 8 years of schooling. In fact, this difference becomes negligible when we equalize educational levels: the means and 
standard deviation values of group 3 are similar to the North American standard (25).

The results of logistic regression allow us to suggest that the ideal combination of comprehension tasks depends on the level of formal education (Table 8). The combination of Body Part Identification, Commands and Complex Ideational Material is the first choice to discriminate between normal subjects and aphasics when schooling is not considered (72.5\% sensitivity and 97.65 specificity) or in middle-educated subjects such as group 2 ( $84.3 \%$ sensitivity and $88.1 \%$ specificity). When evaluating low-educated populations, Complex Ideational Material provokes a floor effect, being too sensitive but at the same time too nonspecific to differentiate between normal and aphasic subjects; in this case, the combination of Body Part Identification and Commands is a better choice $(75.7 \%$ sensitivity and $84.7 \%$ specificity). Commands, on the other hand, appears to be too simple a task to discriminate between high-educated people and aphasics, and in this case Body Part Identification and Complex Ideational Material are the best option (91.4\% sensitivity and $85 \%$ specificity).

Although the BDAE is based on metalinguistic evaluations, it is possible to draw some parallels between the performance in the test and in everyday life. The impairment of comprehension observed in Complex Ideational Material, related to the low educational level, raises some questions that have already been of concern to health professionals. These questions refer to the influence of low education and lack of knowledge of the specific "health" lexicon on the ability of patients and their families to comprehend the diverse kinds of explanations and instructions given by health professionals. This lack of understanding may constitute an additional morbidity factor, especially in chronic diseases such as diabetes and systemic arterial hypertension (37-40).

The results of the present study confirm those available in the current literature concerning the role of schooling as a determinant factor for significant differences in the performance of subjects in oral comprehension tasks. It was even possible to determine the combination of tasks that are most useful in exposing such differences: specific semantic categories (geometric forms, numbers, colors, body parts) and Complex Ideational Material. It is noteworthy that the number of years of formal education exerts a different influence on different tasks, and the same subject can be considered to be "literate" or "functionally illiterate" depending on the complexity of the task.

Regarding age, the results reinforce the idea that some language abilities are resilient during the aging process and thus can be used to differentiate normality from disease conditions. Additional studies are necessary in order to determine the performance of older subjects (above 75 years), especially with respect to visual inference and executive abilities. Studying larger samples of elderly people could also clarify the effect of other individual differences in their cognitive performance, thus avoiding the use of "pure" chronological age as the only indicator of the aging process.

Adjustments of scores according to educational level must be considered when analyzing populations with limited access to school. Further in-depth studies concerning the performance of low-education subjects in the other tests used for diagnosis are needed in order to rule out false-positive results. Moreover, the possible effects of schooling on the condition of brain lesions constitute the next natural step in extending this investigation. 


\section{References}

1. Neils-Strunjas J (1998). Clinical assessment strategies - evaluation of language, comprehension and production by formal test batteries. In: Stemmer B \& Whitaker HA (Editors), Handbook of Neurolinguistics. Academic Press, San Diego, CA, USA.

2. Yasuda K, Nakamura T \& Beckman B (2000). Comprehension and storage of four serially presented radio news stories by mild aphasic subjects. Brain and Language, 75: 399-415.

3. Parente MAMP \& Lecours AR (1988). La influencia de los factores culturales en la neuropsicobiologia y en la neurolingüística. UNESCO, 115: 102-113.

4. Pineda DA, Mejia SE, Rosselli M, Ardila A, Romero MG \& Pérez C (1998). Variabilidad en la prueba de Boston para el diagnóstico de las afasias en adultos laboralmente activos. Revista de Neurología, 26: 962-970.

5. Pineda DA, Rosselli M, Ardila A, Mejia SE, Romero MG \& Pérez C (2000). The Boston Diagnostic Aphasia Examination-Spanish version: the influence of demographic variables. Journal of the International Neuropsychological Society, 6: 802-814.

6. Matute E (1998). Neuropsicología del analfabetismo. Neuropsychologia Latina, 4: 38-47.

7. INEP - Instituto Nacional de Estudos e Pesquisas Educacionais Anísio Teixeira (2003). Mapa do Analfabetismo no Brasil. INEP, Brasília, DF, Brazil.

8. Moreira DA (2003). Analfabetismo Funcional: O Mal Nosso De Cada Dia. Thomson, São Paulo, SP, Brazil.

9. Tfouni LV (1988). Adultos Não Alfabetizados: O Avesso Do Avesso. Pontes, Campinas, SP, Brazil.

10. Obler LK, Nicholas M, Albert ML \& Woodward S (1985). On comprehension across the adult lifespan. Cortex, 21: 273-280.

11. Dixon RA, Hertzog C, Friesen IC \& Hultsch DF (1994). Assessment of intraindividual change in text recall of elderly adults. In: Brownell $\mathrm{HH}$ \& Joanette $\mathrm{Y}$ (Editors), Narrative Discourse in Neurologically Impaired and Normal Aging Adults. Singular Publishing Group, San Diego, CA, USA.

12. Hupet M \& Nef F (1994). Vieillissement cognitif et langage. In: Van der Linden M \& Hupet M (Editors), Le Vieillissement Cognitif. Presses Universitaires Françaises, Belgium.

13. Miceli G, Caltagirone C, Gainotti G, Masullo C et al. (1981). Influence of age, sex, literacy and pathologic lesion on incidence, severity and type of aphasia. Acta Neurologica Scandinavica, 64: 370-382.

14. Trudeau N, Goulet P \& Joanette $Y$ (1993). Age and type of aphasia. Acta Neurologica Belgica, 93: 283-289.

15. Connor LT, Obler LK, Tocco M, Fitzpatrick PM \& Albert ML (2001). Effect of socioeconomic status on aphasia severity and recovery. Brain and Language, 78: 254-257.

16. Filley CM \& Cullum CM (1997). Education and cognitive function in Alzheimer's disease. Neuropsychiatry, Neuropsychology, and Behavioral Neurology, 10: 48-51.

17. Caramelli P, Poissant A, Gauthier S, Bellavance A, Gauvreau D, Lecours AR \& Joanette Y (1997). Educational level and neuropsychological heterogeneity in dementia of the Alzheimer type. Alzheimer Disease and Associated Disorders, 11: 9-15.

18. Reitan RM \& Wolfson D (1995). Influence of age and education on neuropsychological test results. Clinical Neuropsychology, 9: 151158.

19. Rosselli M, Ardila A \& Rosas P (1990). Neuropsychological assessment in illiterates. II. Language and praxic abilities. Brain and Cognition, 12: 281-296.
20. Finlayson MAJ, Johnson KA \& Reitan RM (1977). Relationship of level of education to neuropsychological measures in brain-damaged and non-brain damaged adults. Journal of Consulting and Clinical Psychology, 45: 536-542.

21. Ardila A (1995). Direction of research in cross-cultural neuropsychology. Journal of Clinical and Experimental Neuropsychology, 17: 143-151.

22. Lowenstein DA, Arguelles T, Arguelles S \& Linn-Fuentes P (1994). Potential cultural bias in the neuropsychological assessment of the older adult. Journal of Clinical and Experimental Neuropsychology, 16: 623-629.

23. Ogunniyi A, Lekwauwa UG \& Osuntokun BO (1991). Influence of education on aspects of cognitive functions in non-demented elderly Nigerians. Neuroepidemiology, 10: 246-250.

24. Bertolucci PHF, Brucki SMD, Camparcci SR \& Juliano Y (1994). O mini-exame do estado mental em uma população geral - Impacto da escolaridade. Arquivos de Neuropsiquiatria, 52: 1-7.

25. Goodglass H \& Kaplan E (1983). The Assessment of Aphasia and Related Disorders. 2nd edn. Lea \& Febiger, Philadelphia, PA, USA.

26. Pfeffer RI, Kurosaki TT, Harrah CH, Chance JM \& Filos S (1982). Measurement of functional activities in older adults in the community. Journal of Gerontology, 37: 323-329.

27. Radanovic M \& Mansur LL (2002). Performance of a Brazilian population sample in the Boston Diagnostic Aphasia Examination. A pilot study. Brazilian Journal of Medical and Biological Research, 35: 305-317.

28. Mansur LL, Radanovic M, Rüegg D, Mendonça LIZ \& Scaff M (2002). Descriptive study of 192 adults with speech and language disturbances. São Paulo Medical Journal, 120: 170-174.

29. Rosselli M, Ardila A, Florez A \& Castro C (1990). Normative data on the Boston Diagnostic Aphasia Examination in a Spanish-speaking population. Journal of Clinical and Experimental Neuropsychology, 12: 313-322.

30. Baltes PB \& Lindenberger $U$ (1997). Emergence of a powerful connection between sensory and cognitive functions across the adult life span. A new window to the study of cognitive aging? Psychology and Aging, 12: 12-21.

31. Ryan EB (1995). Normal aging and language. In: Lubinski R (Editor), Dementia and Communication. Singular Publishing Group, San Diego, CA, USA.

32. Manly JJ, Jacobs DM, Sano M, Bell K, Merchant CA, Small SA \& Stern Y (1999). Effect of literacy on neuropsychological test performance in nondemented, education-matched elders. Journal of the International Neuropsychological Society, 5: 191-202.

33. UNESCO Institute for Statistics (1999). [Internet]. Educational attainment of the adult population, by age group and gender. Available at: http://www.uis.unesco.org/TEMPLATE/html/ Exceltables/WEI2002/table4.xIs.

34. Schneider BA, Daneman M \& Pichora-Fuller MK (2002). Listening in aging adults: from discourse comprehension to psychoacoustics. Canadian Journal of Experimental Psychology, 56: 139-152.

35. Lecours AR, Mehler J, Parente MA et al. (1987). Illiteracy and brain damage - 1. Aphasia testing in culturally contrasted populations (control subjects). Neuropsychologia, 25: 231-245.

36. Kolinsky R (1996) Conséquences cognitives de l'illettrisme. In: Carbonnel S, Gillet PM-D, Martory M-D \& Valdois S (Editors), Approche Cognitive des Troubles de la Lecture et de L'Écriture Chez l'Enfant et L'Adulte. Collection Neuropsychologie. Solal, Marseille, France. 
37. Fitzgerald DW, Marotte C, Verdier RI, Johnson WD \& Pape JW (2002). Comprehension during informed consent in a less-developed country. Lancet, 360: 1301-1302.

38. Schillinger D, Piette J, Grumbach K, Wang F, Wilson C, Daher C, Leong-Grotz K, Castro C \& Bindman AB (2003). Closing the loop: physician communication with diabetic patients who have low health literacy. Archives of Internal Medicine, 163: 83-90.

39. Andrus MR \& Roth MT (2002). Health literacy: a review. Pharmacotherapy, 22: 282-302

40. Raich PC, Plomer KD \& Coyne CA (2001). Literacy, comprehension, and informed consent in clinical research. Cancer Investigation, 19: 437-445. 


\section{Appendix - Auditory Comprehension tasks \\ - BDAE - Brazilian Portuguese version ${ }^{1}$}

\section{A. Discriminação Auditiva ${ }^{1,2}$}

Apresentar os cartões 2 e 3 separadamente. O paciente deve olhar todas as figuras no cartão apresentado antes de iniciar. Então, pedir a ele para apontar cada figura ou símbolo, dizendo "Mostre-me o.....". Alternar aleatoriamente de uma categoria para outra. É permitida uma repetição, se solicitada. Se o paciente não encontrar a categoria correta, então mostrá-la, para excluir as demais e repetir o nome do item a ser identificado. (Escore na coluna "Pista"). A discriminação correta ("Identificação") tem escore de 2 pontos se ocorrer em 5 segundos e, caso contrário, 1 ponto. Atenção: a categoria correta sem discriminação correta tem escore de 1/2 ponto (checar "Categoria"). Total de estímulos: 36 (seis em cada categoria semântica). Pontuação máxima: 72.

Table 1. Appendix

\begin{tabular}{|c|c|c|c|c|c|c|c|c|c|c|c|}
\hline \multirow[t]{3}{*}{ Cartão 2} & \multicolumn{2}{|c|}{ Identificação } & \multirow{3}{*}{$\frac{\text { Categoria }}{1 / 2 \text { ponto }}$} & \multirow{3}{*}{$\frac{\text { Pista }}{1 / 2 \text { ponto }}$} & \multirow{3}{*}{$\frac{\text { Falha }}{0}$} & \multirow[t]{3}{*}{ Cartão 3} & \multicolumn{2}{|c|}{ Identificação } & \multirow{3}{*}{$\frac{\text { Categoria }}{1 / 2 \text { ponto }}$} & \multirow{3}{*}{$\frac{\text { Pista }}{1 / 2 \text { ponto }}$} & \multirow{3}{*}{$\frac{\text { Falha }}{0}$} \\
\hline & $<5^{\prime \prime}$ & $>5^{\prime \prime}$ & & & & & $<5^{\prime \prime}$ & $>5^{\prime \prime}$ & & & \\
\hline & 2 pontos & 1 ponto & & & & & 2 pontos & 1 ponto & & & \\
\hline \multicolumn{6}{|l|}{ Objetos } & \multicolumn{6}{|l|}{ Ações } \\
\hline \multicolumn{3}{|l|}{ Cadeira } & & & & \multicolumn{3}{|l|}{ Fumando } & & & \\
\hline \multicolumn{3}{|l|}{ Chave } & & & & \multicolumn{3}{|l|}{ Bebendo } & & & \\
\hline \multicolumn{3}{|l|}{ Letras } & & & & \multicolumn{3}{|l|}{ Cores } & & & \\
\hline \multicolumn{3}{|l|}{$\mathrm{L}$} & & & & \multicolumn{3}{|l|}{ Azul } & & & \\
\hline \multicolumn{3}{|l|}{$\mathrm{H}$} & & & & \multicolumn{3}{|l|}{ Marrom } & & & \\
\hline \multicolumn{3}{|l|}{ Formas } & & & & \multicolumn{3}{|l|}{ Números } & & & \\
\hline \multicolumn{3}{|l|}{ Círculo } & & & & \multicolumn{3}{|l|}{7} & & & \\
\hline \multicolumn{3}{|l|}{ Espiral } & & & & \multicolumn{3}{|l|}{42} & & & \\
\hline
\end{tabular}

\section{B. Identificação de Partes do Corpo ${ }^{1,2}$}

Pedir ao paciente para apontar as seguintes partes do corpo. Registrar as respostas incorretas. Pontuação: Os itens nas primeiras duas colunas têm como escore 1 ponto se reconhecidos imediatamente (dentro de aproximadamente 5 segundos) e 1/2 ponto se identificados corretamente, mas após hesitação. A terceira coluna é para a discriminação direita-esquerda e recebe um total de 2 pontos se todas as 8 forem corretas (a parte do corpo pode estar incorreta conquanto seja feita a discriminação direita-esquerda), 1 ponto se 6 ou 7 itens estiverem corretos e, de outra forma, 0. Total de estímulos: 18. Pontuação máxima: 20.

Table 2. Appendix

\begin{tabular}{|c|c|c|c|c|c|c|c|c|c|c|}
\hline & \multicolumn{2}{|c|}{ Correto } & \multirow[t]{3}{*}{ Falha } & & \multicolumn{2}{|c|}{ Correto } & \multirow[t]{3}{*}{ Falha } & & \multirow[t]{3}{*}{ Correto } & \multirow[t]{3}{*}{ Falha } \\
\hline & $<5^{\prime \prime}$ & $>5^{\prime \prime}$ & & & $<5 "$ & $>5^{\prime \prime}$ & & & & \\
\hline & 1 ponto & o $1 / 2$ ponto & & & 1 ponto & $1 / 2$ ponto & & & & \\
\hline Orelha & & & & Pulso & & & & Orelha direita & & \\
\hline Nariz & & & & Polegar & & & & Ombro esquerdo & & \\
\hline Ombro & & & & Coxa & & & & Joelho esquerdo & & \\
\hline
\end{tabular}

${ }^{1}$ This Appendix includes only a few examples of each task, not the complete BDAE.

${ }^{2}$ In sections A, B and C, the original stimuli were just translated. 


\section{Ordens ${ }^{1,2}$}

O paciente deverá realizar as seguintes ordens, pontuando-se cada elemento sublinhado que ele realizar. É permitida uma repetição se solicitada, mas a ordem deve sempre ser repetida totalmente, não segmentada. Total de estímulos: 5 frases com 15 estímulos. Pontuação máxima: 15

Feche a mão.

Ponha o lápis acima do cartão, então ponha-o de volta no lugar.

Toque cada ombro duas vezes com dois dedos mantendo os olhos fechados.

\section{Material Ideacional Complexo ${ }^{3}$}

A única resposta requisitada é concordar ou discordar. Ambas as questões "a" e "b" para cada item numerado devem ser respondidas corretamente para receber crédito de 1 ponto. Uma repetição para cada questão é permitida. Total de estímulos: 8 questões e 4 textos. Pontuação máxima: 12.

Table 3. Appendix

\begin{tabular}{|c|c|c|}
\hline Uma rolha de cortiça afunda na água? & $1 a$ & \\
\hline Um martelo é bom para cortar madeira? & & $2 a$ \\
\hline Uma pedra afunda na água? & $1 b$ & \\
\hline Você pode usar um martelo para bater pregos? & & $2 b$ \\
\hline
\end{tabular}

Vou ler uma pequena história e depois vou fazer algumas perguntas sobre ela. Você está pronto? (Leia com velocidade normal).

Sr. João tinha que ir para o Paraná visitar seu irmão. Como estava com pressa, ele decidiu pegar um avião. Sua esposa levou-o ao aeroporto, mas no caminho, o pneu furou. Graças à ajuda de um motorista de táxi que passava, eles chegaram ao aeroporto a tempo de pegar o avião.

Table 4. Appendix

\begin{tabular}{lcc|}
\hline O Sr. João perdeu o avião? & $5 a$ & \\
O Sr. João estava indo para o Paraná? & & $6 \mathrm{a}$ \\
Ele chegou ao aeroporto a tempo? & $5 \mathrm{~b}$ & \\
Ele estava vindo do Paraná? & & $6 \mathrm{~b}$
\end{tabular}

${ }^{3}$ Section D contains only one example of each type of question used. The simple questions were just translated. The texts were both translated and adapted to Portuguese taking into account the context, extension, number of paragraphs, phrases, and lexical characteristics. 